\title{
The Effect Of Return On Assets, Current Ratio, Debt To Equity Ratio And Underwriter's Reputation On Underpricing During Initial Public Offering (IPO) On The Indonesia Stock Exchange In Period 2014-2018
}

\author{
Jenniari Shella Damanik ${ }^{1}$, Ferikawita M. Sembiring ${ }^{2}$ \\ \{jenniarishella95@gmail.com¹, ferikawita.magdalena@lecture.unjani.ac.id²\} \\ Management Department of Jenderal Achmad Yani University, Cimahi, Indonesia ${ }^{1}$, Management Department \\ of Jenderal Achmad Yani University, Cimahi, Indonesia ${ }^{2}$
}

\begin{abstract}
This research was aimed to find out the influence of financial and non-financial information to underpricing in companies that conducted Initial Public Offering. Variables used in this study are Return on Assets (ROA), Current Ratio (CR), Debt to Equity Ratio (DER), and Underwriter's Reputation. The population in this research was the companies that conduct IPO listed in the Indonesia Stock Exchange within 2014-2018 outside the companies from banking. The data analysis uses multiple regression method and the samples of this study use purposive sampling method with the number of samples are 85 companies. The result showed that Return on Assets (ROA) and Underwriter's Reputation have significantly influenced the underpricing, while other independent variables such as Debt to Equity Ratio (DER) and Current Ratio (CR) have not significantly influenced the underpricing. The result showed that simultaneously Return on Assets (ROA), Current Ratio (CR), Debt to Equity Ratio (DER) and an Underwriter's Reputation have significantly influence the underpricing.
\end{abstract}

Keywords: Current Ratio (CR), Debt to Equity Ratio (DER), Initial Public Offering (IPO), Return on Assets (ROA), Underwriter's Reputation, Underpricing

\section{Introduction}

Along with developing the economy in Indonesia, a company needs to develop and maintain its existence. In developing business and financing the company's operational activities, a company's capital availability is what a company needs. There are two ways to get this capital, namely by utilizing existing sources within the company itself or by looking for other sources of capital that are outside the company[1].

Companies can use retained earnings as an additional source of funding from within the company. However, in developing a company, sometimes, this source of funding is still not sufficient. Therefore the company needs to seek the availability of additional sources of funds from outside the company[2]. External sources of funding can be in the form of selling stocks owned by the company and selling to investors in the capital market[3].

A capital market is where the supply and demand process for securities such as bonds and 
stocks occurs[4]. The capital market is also an intermediary between issuers and investors. In capital market activities, these issuers and investors have different interests. Issuers see the capital market as an alternative source of obtaining additional funds. In contrast, the capital market is seen by investors as an alternative for investing and obtaining optimal profits[5]. Companies can use the capital market to increase outside funding by trading their stocks to the public to become a public company or what is often referred to as go public. Issuers see the capital market as an alternative source of obtaining additional funds. In contrast, the capital market is seen by investors as an alternative for investing and obtaining optimal profits[6].

However, before a company becomes a publicly listed company, the first thing the company needs to do is conduct an initial public offering (IPO). IPO itself is an activity carried out in the primary market to sell stocks for the first time to the public and then be traded on the secondary market. The price of stocks sold in the primary market results from an agreement between the issuer and the underwriter. This underwriter will later become a liaison between the company and the capital market. It takes much consideration in determining the price of stocks to be sold, this is because many cases occur in the failure of this IPO, which can harm the company (the issuer) and its underwriters[7]. This failure is usually because the company and underwriters have difficulty determining the offering price of stocks for sale on the primary market. Lack of information regarding relevant prices and company stocks that have never been traded causes stocks in the primary market to be lower than when traded in the secondary market or is often referred to as the underpricing phenomenon[8]. On the other hand, if the price of stocks sold in the primary market is higher than the selling price in the secondary market, it is known as overpricing[9].

This underpricing phenomenon will be beneficial for investors because investors will get an initial return. On the contrary, companies that do IPO do not expect underpricing because it will harm the company. After all, the company will not get maximum funds[9].

Table 1. Companies Participating in the Initial Public Offering (IPO) for the 2014-2018 Period

\begin{tabular}{cccccc}
\hline Year & $\begin{array}{c}\text { Total } \\
\text { Companies } \\
\text { participating } \\
\text { in the IPO }\end{array}$ & $\begin{array}{c}\text { Under } \\
\text { pricing }\end{array}$ & $\begin{array}{c}\text { Over } \\
\text { pricing }\end{array}$ & Consistent & $\begin{array}{c}\text { Underpricing } \\
\text { Percentage }\end{array}$ \\
\hline 2013 & 25 & & & & \\
2014 & 23 & 20 & 2 & 1 & $68 \%$ \\
2015 & 17 & 15 & 1 & 1 & $86,95 \%$ \\
2016 & 15 & 14 & 1 & - & $88,23 \%$ \\
2017 & 36 & 33 & 3 & - & $93,33 \%$ \\
2018 & 58 & 54 & 4 & - & $93,66 \%$ \\
Total & 149 & 136 & 11 & 3 & \\
\hline
\end{tabular}

Source: e-bursa.com, data processed (2019) 
It can be seen in table 1.1. In this study, the research year is 2014-2018. 2014 was chosen as the initial year due to a decrease in companies conducting IPOs than the previous year; this was due to the election, which made companies refrain from conducting IPOs (www.cnnindonesia.com, 2014). The decline continued into 2016 due to global and domestic economic conditions affecting the capital market (kompas.com). From 2017 to 2018, there was an increase in Indonesia's macroeconomy, which encouraged companies to retake the floor on the Indonesia Stock Exchange (BEI) (Bisnis.com).

With the existence of phenomena and inconsistencies in previous research, the authors are interested in further research on "The Effect Of Return On Assets, Current Ratio, Debt To Equity Ratio And Underwriter's Reputation On Underpricing During Initial Public Offering (IPO) On The Indonesia Stock Exchange In Period 2014-2018"

\section{Literature Review}

\subsection{Investment}

Investment is a commitment to several funds or other resources that are carried out at this time, to obtain several benefits in the future[10]. Investment can be defined as long-term investment activity in an asset, hoping that it will benefit the future. Companies that require additional funds will use this investment by selling securities such as bonds or stocks to the capital market.

\subsection{Capital Market}

A capital market is a place where various parties, especially selling stocks and bonds, with the aim that the proceeds from the sale will be used as additional funds or to strengthen the company's capital[11].

\subsection{Stock}

Stocks are proof of ownership of capital/funds in a company. Stocks can also be interpreted as paper with an exact nominal value and company name followed by each holder's rights and obligations)[11].

\subsection{Initial Public Offering (IPO)}

Some stocks offered on the capital market for the first time to the general public are called the initial public offering or what is known as go public[12].

\subsection{Underpricing}

Underpricing is a condition in which the price of stocks traded at the time of offering on the primary market is lower than in the secondary market[13]. This underpricing can be calculated using the initial return.

\subsection{Return on Asset}

Return on assets is used to show a company's ability to generate profits using the total assets 
owned by the company[14].

\subsection{Current Ratio}

The current ratio is a ratio to measure the ability of a company to pay short-term obligations or debts that are due. This shows how many current assets the company has to cover its short-term obligations that are due[15].

\subsection{Debt to Equity Ratio}

The debt to equity ratio is used to assess debt to equity. This ratio can be used to determine the company's capital, which is used as collateral[14].

\subsection{Underwriter's Reputation}

An underwriter is an underwriter for every company that will issue its stocks on the capital market. The issuer with an underwriter determines the share price set at the time of the IPO. The underwriter's job is to guarantee the sale of securities offered in a public offering as predicted[11].

The framework used in the research is as follows:

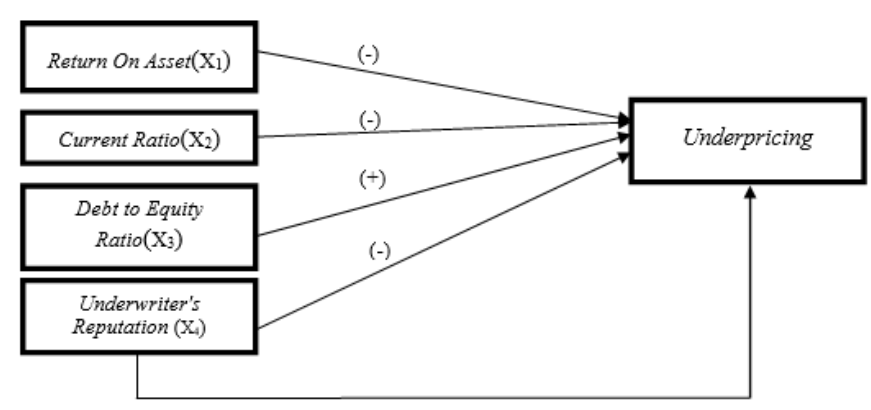

Fig.1. The Framework

Figure 2.1 explains the relationship between the independent variables (return on assets, current ratio, debt to equity ratio, and underwriter's reputation) to the dependent variable (underpricing) either partially or simultaneously.

\section{Research Method}

\subsection{Research Approach}

In this study, the authors used quantitative research methods because this study collected data in the form of numbers, then analyzed quantitatively using statistics. A quantitative method is a scientific approach to deciding on numbers and analysis using statistics[16].

\subsection{Object of Research}


The objects in this study are the return on assets, current ratio, debt to equity ratio, and the underwriters' reputation in companies that have gone public/initial public offering (IPO) and underpriced in the 2014-2018 period on the Indonesia Stock Exchange.

\subsection{Population and Sample}

This study's population were all companies that experienced underpricing during the IPO in 2014 - 2018, as many as 136 companies. Determination of the sample using a purposive sampling method. The sample selection criteria in this study are as follows:

1. Companies participating in the IPO on the Indonesia Stock Exchange in the 2014-2018 period

2. Companies that have financial statements one year before the IPO

3. Companies engaged in the non-financial sector and listed on the Indonesia Stock Exchange during the period 2014-2018. The reason why banking companies and other financial institutions are issued is because companies from these sectors have different financial ratios with companies from other sectors. The main difference is that the balance sheet and income statement components owned by banks are different from the balance sheet and profit and loss statements owned by non-bank companies.

4. Company data, mainly return on assets, does not have a negative value because it indicates that the company is experiencing a loss.

\subsection{Type of Data}

The research data used in this study is secondary data. In this study, researchers used crosssection data. The data is obtained from published company data and companies listed on the Indonesia Stock Exchange that conducted an initial public offering (IPO) in 2014-2018.

\subsection{Data Collection}

In this study, data collection techniques were carried out using documentation and literature study methods, namely collecting data by reviewing various literature. Researchers used historical data from the sites www.idx.co.id and www.e-bursa.com.

\subsection{Operationalization of Research Variables}

Table 2. Operationalization of Variables

\begin{tabular}{lll}
\hline Variable & \multicolumn{1}{c}{ Description } & Indicator \\
\hline Return on & $\begin{array}{l}\text { Return on assets is used to show a company's } \\
\text { ability to generate profits using the company's } \\
\text { total assets }\end{array}$ & ROA $=\frac{\text { EAT }}{\text { Total Asset }} \times 100 \%$ \\
Asset (X1) & $\begin{array}{l}\text { The current ratio is a ratio to measure a } \\
\text { company's ability to pay short-term } \\
\text { obligations or debts that are due. This shows } \\
\text { how many current assets the company has to }\end{array}$ & $\mathrm{CR}=\frac{\text { current assets }}{\text { current liabilities }} \times 100 \%$
\end{tabular}


cover its short-term obligations that are due

Debt to The debt to equity ratio is used to assess debt Equity Ratio to equity. This ratio can be used to determine (X3) the company's capital, which is used as collateral

Underwriter' An underwriter is an underwriter for every $\mathrm{S}$ Reputation $(\mathrm{X}$

4)

Underpricing (Y) company that will issue its stocks on the capital market.

Underpricing is a condition in which the price of stocks traded at the time of offering on the primary market is lower than in the secondary market

$$
\mathrm{DER}=\frac{\text { total liabilities }}{\text { total equity }}
$$

The underwriter's reputation does not use a calculation formula, but instead uses a dummy assessment[17]:

1. If the underwriter has a good reputation then it is given a score of 1

2. If the underwriter does not have a good reputation then it is given a score of 0

$$
\mathrm{UP}=\frac{\text { closing price-offering price }}{\text { offering price }} \times 100 \%
$$

\section{Result And Discussion}

\subsection{Classic Assumption Test}

\begin{tabular}{|c|c|c|c|}
\hline $\begin{array}{l}\text { Testing } \\
\text { Criteria }\end{array}$ & Method & Result & Information \\
\hline Normality & Jarque Bera Probability & $\begin{array}{l}\text { less than } 0.05(<0.05) \text {, } \\
\text { namely } 0.037\end{array}$ & $\begin{array}{l}\text { The data in this study were } \\
\text { not normally distributed. [18] } \\
\text { and[19] state that data that is } \\
\text { more than } 30 \text { is said to be a } \\
\text { large sample, so it can be } \\
\text { assumed to be normally } \\
\text { distributed. }\end{array}$ \\
\hline Multicollinearity & $\begin{array}{l}\text { VIF (Variance Inflation } \\
\text { Factor) }\end{array}$ & $\begin{array}{l}\text { All independent variables } \\
\text { have VIF value }<10 \text { with } \\
\text { tolerance limit }>0,1\end{array}$ & $\begin{array}{l}\text { There is no } \\
\text { multicollinearity }\end{array}$ \\
\hline Heteroscedasticity & $\begin{array}{l}\text { Heteroskedasticity Test: } \\
\text { White }\end{array}$ & $\begin{array}{l}\text { The pro-chi-square value } \\
\text { on obs * r-squared of } \\
0.4677 \text {, where the result is } \\
\text { more significant than } 0.05 \\
(>0.05) \text {. }\end{array}$ & $\begin{array}{l}\text { There is no } \\
\text { heteroscedasticity }\end{array}$ \\
\hline
\end{tabular}

Table 3. The Results of Classic Assumption Test 

Autocorrelation
Breusch-Godfrey Serial
The prob chi-square value
of the obs * $\mathrm{r}$ square of
There is no
Correlation LM Test
$0.4296>0.05$
autocorrelation

\subsection{Multiple Linear Regression Analysis}

Table 4. The Results Multiple Linear Regression

\begin{tabular}{|c|c|c|c|c|c|c|}
\hline Variable & $\begin{array}{l}\text { Coeffic } \\
\text { ient }\end{array}$ & $\begin{array}{l}\text { Std } \\
\text { Error }\end{array}$ & $\begin{array}{l}\text { T- } \\
\text { Statisti } \\
\mathbf{k}\end{array}$ & Prob & $\begin{array}{l}\text { P- } \\
\text { Value }\end{array}$ & Decision \\
\hline $\mathrm{C}$ & 50.01741 & 4.954270 & 10.09582 & 0.0000 & 0 & - \\
\hline ROA & -0.683084 & 0.291614 & -2.342426 & 0.0216 & 0.0108 & $\mathrm{H} 0$ rejected \\
\hline $\mathrm{CR}$ & 0.010186 & 0.012991 & 0.784073 & 0.4353 & 0.21765 & H0 accepted \\
\hline DER & 0.004203 & 0.004560 & 0.921595 & 0.3595 & 0.17975 & H0 accepted \\
\hline RU & -19.36154 & 6.031696 & -3.209966 & 0.0019 & 0.00095 & $\mathrm{H} 0$ rejected \\
\hline R-squared & & 0.202734 & & & & \\
\hline Adjusted R-squared & & 0.162871 & & & & \\
\hline F-statistic & & 5.085734 & & & & \\
\hline Prob(F-statistic) & & 0.001056 & & & & \\
\hline
\end{tabular}

Table 4. shows the estimation results with the research model specifications stated in the regression equation as follows:

$$
\mathrm{UP}=50.01741+-0.683084 \mathrm{ROA}+0.010186 \mathrm{CR}+0.004203 \mathrm{DER}+-19.36154 \mathrm{RU}
$$

The results of the multiple linear regression analysis indicate that:

1. The constant value of 50.01741 indicates that if all independent variables have a value of 0 , then the value of the dependent variable is 50.01741 .

2. The variable return on assets has a coefficient value of -0.683084 . This means that each return on the asset has increased by $1 \%$, assuming that other variables are constant so that the underpricing value will decrease by 0.683084 .

3. The variable current ratio has a coefficient value of 0.010186 . This means that each current ratio has increased by $1 \%$ with the assumption that other variables are constant, then the underpricing value will increase by 0.010186 .

4. Debt to equity ratio variable has a coefficient value of 0.004203 . This means that each debt to equity ratio has increased by 1 unit, assuming that the other variables are constant so that the underpricing value will increase by 0.004203 units.

5. Underwriter's reputation variable has a coefficient value of -19.36154 . This means that each underwriter's reputation has increased by $1 \%$ with the assumption that other variables are constant, then the underpricing value will decrease by 19.36154 . 


\subsection{Partial Hypothesis Test (T-Test)}

1. Based on the test results shown in table 4.4, it shows that the return on assets has a p-value of 0.0108 , where this value is less than $0.05(<0.05)$. This shows that $\mathrm{HO}$ is rejected and $\mathrm{Ha}$ is accepted, which means that return on assets has a significant effect on underpricing.

2. Based on the test results shown in table 4.4 show that the current ratio has a p-value of 0.21765 , where this value is more than $0.05(>0.05)$. This shows that $\mathrm{H} 0$ is accepted, and $\mathrm{Ha}$ is rejected, meaning that the current ratio does not affect underpricing.

3. Based on the test results shown in table 4.4, it shows that the debt to equity ratio has a pvalue of 0.17975 , where this value is more than $0.05(>0.05)$. This shows that $\mathrm{H} 0$ is accepted, and $\mathrm{Ha}$ is rejected, meaning that the debt to equity ratio does not affect underpricing.

4. Based on the test results shown in table 4.4 shows that the underwriter's reputation has a pvalue of 0.00095 , where this value is less than $0.05(<0.05)$. This shows that $\mathrm{H} 0$ is rejected and $\mathrm{Ha}$ is accepted, meaning that the underwriter's reputation significantly affects underpricing.

\subsection{Simultaneous Hypothesis Test (F-Test)}

Based on the test results on Table 4.4, it shows that in simultaneously the return on assets, current ratio, debt to equity ratio, and underwriter's reputation have an effect on the underpricing of companies conducting Initial Public Offerings (IPO) on Indonesian Stock Exchange for the 2014-2018 in period. This is indicated by a significance value of 0.001056 , where the value is less than $0.05(<0.05)$, which indicates that $\mathrm{H} 0$ is rejected or accepts Ha.

\subsection{Coefficient of Determination}

Based on table 4.6, it can be seen through the adjusted square, which is 0.162871 or $16.29 \%$. This shows that the contribution of return on assets, current ratio, debt to equity ratio, and underwriter's reputation simultaneously contributed $16.29 \%$ to underpricing. In comparison, the remaining $83.71 \%$ was influenced by other variables not examined in this study.

\section{Conclusions and Suggestions}

\subsection{Conclusions}

Based on the results of research on the factors that influence underpricing, such as return on assets, current ratio, debt to equity ratio, and the reputation of the underwriters in companies conducting initial public offerings (IPO), the following conclusions can be drawn:

1. Return on assets negatively affects underpricing.

2. Current ratio does not affect underpricing.

3. Debt to equity ratio does not affect underpricing.

4. Underwriter's reputation negatively affects underpricing.

\subsection{Suggestions}


Given the limitations of time and resources owned by researchers, researchers have suggestions that can be considered, among others, to perfect this research:

1. For companies that will conduct IPOs in the future, it is advisable to consider factors that will affect underpricing, such as return on assets and the underwriter's reputation in setting the initial public offering price.

2. For potential investors who will invest in companies that do IPO, the results of this study can be used as consideration for choosing IPO stocks that are feasible to buy because, according to the results of this study that the factors that influence underpricing are return on assets and underwriter's reputation. Thus, it is expected to optimize the returns obtained and minimize the risk of the investment made.

3. For future researchers who will examine the IPO, it is advisable to add financial and nonfinancial variables that may influence underpricing such as return on equity, debt to asset ratio, inflation, and auditor reputation.

\section{References}

[1] F. N. Khasani, “Analisis Pengaruh Reputasi Underwriter, Reputasi Auditor, Umur Perusahaan, Financial Leverage, dan Return On Asset terhadap Tingkat Underpricing Saham (Studi pada Perusahaan yang Baru Listing yang Terdaftar Di BEI 2012-2017),” 2018.

[2] Nurrohmah, "Pengaruh Return On Asset, Earning Per Share, dan Debt To Equity Ratio terhadap Underpricing Harga Saham Perusahaan yang Melakukan IPO (Initial Public Offering) di Bursa Efek Indonesia pada Tahun 2016," 2018.

[3] Sopiyan, "Sharia-Compliance Status dan IPO Underpricing : Bukti Empiris Di Indonesia," 2019.

[4] I. G. N. Adhi Partama and G. Gayatri, "Analisis Determinan Underpricing Saham di Bursa Efek Indonesia," E-Jurnal Akunt., p. 2293, 2019, doi: 10.24843/eja.2019.v26.i03.p23.

[5] H. Budi Kuncoro and R. V. Suryaputri, "Analisis Faktor-Faktor yang Mempengaruhi Underpricing Saham Pada Penawaran Umum Perdana Di BEI Periode 2015-2017,” J. Akunt. Trisakti, vol. 6, no. 2, p. 263, 2019, doi: 10.25105/jat.v6i2.5573.

[6] Nurazizah, "Analisis Faktor Faktor yang Mempengaruhi Tingkat Underpricing Pada Saat Initial Public Offering (IPO) Di Bursa Efek Indonesia," vol. 3, no. 3, 2019, doi: 10.31955/mea.vol4.iss1.pp157-167.

[7] M. Waridatussulusi, "Pengaruh Faktor Keuangan dan Non-Keuangan terhadap Tingkat Underpricing Saham Pada Saat Initial Public Offering (IPO) Di Bursa Efek Indonesia Periode 2013-2017,” 2018.

[8] Kurnianto H, "Analisis Pengaruh Karakteristik Perusahaan, Reputasi Underwriter dan Pengungkapan Modal Intelektual terhadap Tingkat Underpricing," 2018.

[9] J. Wibowo, "Pengaruh Likuiditas, Solvabilitas, Profitabilitas, dan Umur Perusahaan Terhadap Tingkat Underpricing pada Perusahaan IPO Di BEI Periode 2012-2016.," 2018.

[10] E. Tandelilin, Portofolio dan Investasi Teori dan Aplikasi, vol. 7, no. 8. Yogyakarta: Kanisius, 2010.

[11] I. Fahmi, Pengantar Manajemen Keuangan (Teori dan Soal Jawab). Bandung: Alfabeta, 2015.

[12] Jogiyanto, Teori portofolio dan analisis investasi (edisi Kesebelas), 10th ed. Yogyakarta: BPFE, 2017.

[13] Purwanto, S. W. Agustiningsih, S. F. Insani, and B. Wahyono, "Fenomena Underpricing pada Perusahaan yang Go Public di Indonesia," Ekon. Bisnis dan Kewirausahaan, vol. III, no. 1, pp. 1-23, 2014.

[14] Kasmir, Analisis Laporan Keuangan. Depok: Rajagrafindo Persada, 2016.

[15] R. Khairani, "Pengaruh Current Ratio, Return On Assets (ROA), dan Debt To Equity Ratio(DER) terhadap Underpricing Saham Pada Saat Initial Public Offering(IPO) Di Bursa Efek Indonesia (BEI)," 
2017.

[16] M. Kuncoro, Mudah Memahami dan Menganalisis Indikator Ekonomi. Yogyakarta: UPP STIM YKPN, 2013.

[17] A. A. G. Jayarendra and N. L. P. Wiagustini, "Pengaruh Reputasi Underwriter, Ukuran Perusahaan, Dan Return On Equity terhadap Underpricing Saat IPO Di BEI," E-Jurnal Manaj., vol. 8, no. 8, pp. 47314758, 2019.

[18] T. Cahyono, Statistika Terapan \& Indikator Kesehatan - Tri Cahyono - Google Buku. Sleman: Deepublish, 2018.

[19] M. Spiegel, Statistik Edisi Ketiga Schaum's Easy Online. Jakarta: Erlangga, 2004. 